\title{
The Role of MicroRNA in Head and Neck Cancer
}

\author{
Yeon Soo Kim iD \\ Department of Otorhinolaryngology, Konyang University Hospital, Konyang University College of Medicine, Daejeon, Korea
}

\author{
두경부암에서 MicroRNA의 진단적 및 치료적 역할 \\ 김연수 \\ 건양대학교 의과대학 이비인후과학교실
}

\author{
Received January 6,2022 \\ Accepted January 13, 2022 \\ Address for correspondence \\ Yeon Soo Kim, MD, PhD \\ Department of Otorhinolaryngology, \\ Konyang University Hospital, \\ Konyang University \\ College of Medicine, \\ 158 Gwanjeodong-ro, Seo-gu, \\ Daejeon 35365, Korea \\ Tel $+82-42-600-6915$ \\ Fax $+82-42-600-8835$ \\ E-mail ionskim@kyuh.ac.kr
}

Head and neck squamous cell carcinoma (HNSCC) include epithelial tumors arising in the structures of aerodigestive tract such as oral and nasal cavity, pharynx, larynx, paranasal sinuses, and local lymph nodes. HNSCC is the sixth most common cancer worldwide, and its prognosis is very poor. MicroRNAs (miRNAs) are small single stranded noncoding RNAs which are about 19-25 nucleotides involved in cell proliferation, development, differentiation and metastasis. It is believed that miRNA alterations correlate with initiation and progression of cancer cell proliferation or inhibition of tumorigenesis especially in development, progression, and metastasis of HNSCC. Altered expression of miRNAs could be novel molecular biomarkers for the diagnosis and prognosis of HNSCC. Despite the advances in cancer treatment, the mortality rate of HNSCC is still high. The potential application of miRNAs for cancer therapy has been demonstrated in many studies. In this review, we discuss the very recent studies on different aspects of miRNA dysregulation with their clinical significance and miRNA-based therapy. Korean J Otorhinolaryngol-Head Neck Surg 2022;65(2):79-85

\section{서 론}

두경부암은 구강, 구인두, 비인두, 후두 등에서 발생하는 암 으로, 기관별 암 발생률이 6번째를 차지하고 있다. 최근 새로 운 암 치료법들이 발전하며 암에 대한 치료율이 점차 향상되 고 있지만, 진행성 두경부암의 경우에서 5년 생존율은 아직 $50 \%$ 를 넘지 못하고 있다. 이를 극복하기 위한 다양한 연구에 도 불구하고 지난 20년간 생존율이 크게 변하지 않았다. 두 경부암에서의 치료는 수술, 방사선 치료, 항암 치료가 주를 이루고 있다. 최근 마이크로 RNA (microRNAs, miRNAs) 는 두경부암과의 연관성에 대한 여러 연구 결과를 통해 두경 부암 진단 및 치료 효과 예측 표지자 및 치료제로서의 가능

This is an Open Access article distributed under the terms of the Creative Commons Attribution Non-Commercial License (https://creativecommons.org/licenses/by-nc/4.0) which permits unrestricted non-commercial use, distribution, and reproduction in any medium, provided the original work is properly cited.
성이 기대되고 있다.

mRNA와 같은 일부 RNA는 단백질로 번역(translation)하 는 역할을 하지만 non-coding RNA (ncRNA)는 단백질로 번역되지 않고 전사(transcription) 및 번역을 조절하여 유전 자 발현을 조절하는 역할을 한다. 이러한 ncRNA에는 long ncRNA (lncRNA), miRNA, small interfering RNA (siR$\mathrm{NA}$ ) 등이 포함된다. 이러한 ncRNA의 조절 장애는 암의 성 장 및 진행에 관여하기도 한다. 이 중 특히 miRNA는 1993년 미국 다트머스대 의대 교수인 빅터 앰브로스가 예쁜꼬마선충 (caenorhabditis elegans)의 배아 발생에 영향을 주는 유전자 를 찾다가 처음으로 발견하였다. miRNA는 유전자 발현을 조 절함으로써 세포분화, 성장, 증식 등 다양한 생명현상에 관여 하며, 특히 여러 악성종양에서 특이적 발현양상을 보인다. 종 양유전자(oncogene) 혹은 종양억제 유전자(tumor suppressor gene)로 작용하는 miRNA가 악성종양의 발암과정에 관 
여하는 것으로 알려져 있다.,2) 암과 관련된 miRNA를 oncogenic miRNA (oncomiR)라고 하며, 최근 여러 종양에서의 oncomiR 발현 분석 정보들은 다양한 암의 조기진단, 예후 예 측을 통하여 임상에 활용 가능성을 시사하고 있다.,2) miRNA 의 발현 변화가 종양의 초기와 진행단계에서 매우 중요하다는 실험 결과가 최근 발표되고 있으며, 종양에서 miRNA의 비정 상적인 발현은 염색체 결손, 증폭, 점돌연변이와 같은 유전적 인 원인 또는 비정상적인 DNA 메틸화 등과 같은 후생유전에 의한 것으로 알려져 있다. ${ }^{3)}$

miRNA가 세포 안에서 발생, 성장, 노화 등 다양한 생명 현상과 관련된 유전자 발현을 조절하기 때문에 최근에는 miRNA를 이용해 치료제를 개발하려는 연구가 활발하게 이 루어지고 있다. 생체 내에서 RNA 분자를 전달하는 기술의 발전으로 인해 miRNA 기반의 치료법이 실현 가능하게 되었 다. miRNA 제어에 의한 종양 관련 유전자 발현조절은 매우 중요한 종양 조기진단, 치료 및 예후측정 방법이 될 것으로 예상하고 있다. ${ }^{4)}$ 본 종설은 두경부암과 miRNA 간의 다양한 관계 및 그 기전에 대해 알아보고, 진단과 예후마커로서의 가 능성과 miRNA을 이용한 치료법에 대해 논의하고자 한다.

\section{본 론}

\section{두경부암 촉진 miRNA (oncomiRs)}

과거 연구에 따르면 일부 miRNA의 과발현이 타겟 mRNA 를 억제하고 전암병변에서 두경부암으로 진행되는 데 영향을 미친다고 알려져 있다. 전이암과 비전이암 사이의 miRNA 발 현은 차이가 있으며 일부 miRNA의 발현량의 증가는 암의 예후에 영향을 미치기도 한다. 그 중 miR-10b는 두경부암세 포주에서 증가되어 있고 세포 증식을 유도하는 것으로 보고 되었다. ${ }^{5)}$ 또한 $\mathrm{miR}-10 \mathrm{~b}$ 는 구강암 세포의 이동 및 침습을 증 가시킨다. ${ }^{6} \mathrm{miR}-21$ 은 두경부암에서 예후인자로 연구되고 있 다. miR-21은 구강암에서 세포자멸사(apoptosis)와 전이에 관여하는 programmed cell death 4 (PDCD4)를 억제한다고 밝혀졌다. ${ }^{7)} \mathrm{miR}-21$ 증가는 구강암의 림프절 전이 단계와 상 관관계가 있다. ${ }^{8)}$ 따라서 두경부암에서 $\mathrm{miR}-21$ 의 발현은 악 성 예후를 의미한다.9) miR-31은 두경부암에서 발현이 증가 되어 있으며, hypoxia-inducible factor- $1 \alpha(\mathrm{HIF}-1 \alpha)$ 를 활성 화하고 factor inhibiting HIF-1을 통해 종양 발생을 증가시 킨다. miR-31은 산소 공급이 충분할 때만 종양유전자로 기 능한다. $\mathrm{miR}-31$ 은 또한 구강암 초기 단계의 증식 및 종양유 전성을 촉진한다고 알려졌다. ${ }^{10)} \mathrm{miR}-93$ 의 발현 증가는 두경 부암의 림프절 전이와 관련이 있다. ${ }^{11)}$ 다른 암종에서 miR-93 은 상피간엽이행(Epithelial-Mesenchymal Transition, EMT)
조절, 혈관 신생, 암세포와 세포외기질 사이의 유착을 방해 하여 종양 침범 및 전이를 촉진한다. ${ }^{12)}$ 그러나 두경부암에서 miR-93의 표적 유전자는 아직 밝혀지지 않았다. miR-134의 높은 발현은 림프절 전이와 사망률에 연관이 있으며, 이는 종양 억제인자인 WW domain-containing oxidoreductase (WWOX) 유전자를 표적화하여 miR-134 기능변화와 관련 이 있다. miR-155는 종양 촉진 miRNA로서 림프종 및 여러 고형 종양에서 강력한 oncomiR 역할을 한다. 두경부암에서 $\mathrm{miR}-155$ 의 증가는 조직학적 병기와 상관관계가 있으며 잠재 적 예후인자로 사용될 수 있다. ${ }^{13)} \mathrm{miR}-155-5 \mathrm{p}$ 는 종양의 전이 및 악성 예후와 관련이 있으며 miR-155-5p 억제제는 suppressor of cytokine signaling 1 (SOCS1)을 활성화하여 signal transducer and activator of transcription (STAT3)의 활성화를 감소시킨다. ${ }^{14)} \mathrm{miR}-181 \mathrm{~b}$ 는 림프절 전이가 있는 구 강암 환자에서 발현도가 높다. ${ }^{15)}$ 이전 연구에 따르면 miR-181 은 구강 백반증이 이형성증 이후 침습성 암종으로 진행되는 동안 증가되었다. ${ }^{16)}$ 두경부암에서 miR-211은 transforming growth factor $\beta$ type II receptor (TGFßRII)를 표적으로 하 여 종양 침범 및 전이를 촉진한다. 두경부암의 전이 중 발현 되는 miR-211과 TGFBRII 사이에는 역 상관관계가 있다.17) 이전 연구에서는 miR-211이 정상 조직에 비하여 구강암 조 직에서 N2 stage 림프절 전이 및 혈관 침범이 관찰될 때 유의 미하게 발현된 것으로 나타났다. ${ }^{18)} \mathrm{miR}-223$ 은 종양발생에 중 요한 역할을 하며 그 기능은 암 유형에 따라 다르다. 조혈성 악성종양에서 miR-223의 수치가 감소하는 것이 관찰되었지 만, 여러 유형의 두경부암에서는 오히려 $\mathrm{miR}-223$ 의 발현 증 가가 나타났다. ${ }^{19)}$ 두경부암 촉진 miRNA에 대하여 Table 1에 정리하였다.

\section{두경부암 억제 miRNA (tumor suppressor miRNAs)}

일반적으로 두경부암에서 암 억제 miRNA는 감소되어 있 다. 문헌 리뷰에 따르면 $\mathrm{miR}-1$ 은 두경부암에서 감소된다. miR-1은 세포 이동과 침습을 매개하는 유전자 Transgelin 2 (TAGLN2)를 표적해서 두경부암의 전이를 억제할 수 있는 것 으로 나타났다. ${ }^{20)}$ let-7d는 let-7 miRNA 군의 일종으로 RAS 단백질 군을 포함하는 신호 전달네트워크의 교란으로 종양 억제제 역할을 한다. ${ }^{21)}$ 구강암 조직, 국소 및 원격 전이 림프 절에서 let-7d 발현 감소가 보고되었다. ${ }^{22,23)}$ 결국, 두경부암에 서 let-7d 발현이 감소하면 예후가 좋지 않다. miR-17과 miR$20 \mathrm{a}$ 는 모두 진행된 구강암에서 하향 조절되며, 이들의 발현 수준은 진행된 TNM 병기와 림프절 전이에 의해 음성적으로 조절된다. ${ }^{24)} \mathrm{miR}-29$ 계열은 두경부암 조직 및 세포주에서 유 의하게 하향 조절되어 laminin $\gamma 2$ (LAMC2) 및 $\alpha 6$ integrin 
(ITGA6)을 통해 두경부암의 전이에 기여함을 시사한다. ${ }^{25)}$ 이 전 연구에서 $\mathrm{EMT}$ 과정에 기여하는 $\mathrm{TGF}-\beta$ 신호 전달이 $\mathrm{miR}-$ 29 패밀리의 발현을 억제하고 세포외기질 extracellular matrix 구성 요소의 발현을 촉진한다는 것을 입증되었다. ${ }^{26)} \mathrm{miR}-34 \mathrm{~b}$ 는 Snail을 타깃으로 하여 EMT에서 중요한 역할을 한다. ${ }^{27)}$ 두경부암에서 miR-34 b/c는 감소되어 있다. 그러나 표적 유 전자는 아직 확인되지 않았다. ${ }^{28)} \mathrm{miR}-34$ 의 종양 억제 역할은 cyclin 의존성 키나아제 4 (cyclin dependent kinase, CDK4) 및 $\mathrm{CDK} 6$ 와 같은 세포주기 단백질의 발현, $\mathrm{BCL} 2$ 및 전이와 관련된 항세포자멸단백질(MET, Notch, MYC 및 AXL)의 발현에 영향을 주는 표적 $\mathrm{mRNA}$ 와 밀접한 연관이 확인되었 다. 또한, 두경부암세포주에서 miR-99 family의 이소성 형질 감염은 세포 이동을 감소시키며, 이는 miR-99 family가 $\mathrm{IG}^{-}$ $\mathrm{F} 1 \mathrm{R}$ 및 $\mathrm{mTOR}$ 신호 전달 경로를 표적으로 함으로써 종양 억 제인자로서의 역할을 시사한다. ${ }^{19)} \mathrm{miR}-125 \mathrm{~b}$ 는 기질 matrix metalloproteinase-13 (MMP13)의 하향 조절을 통해 피부암 에서 암세포의 증식, 이동 및 침투를 억제함으로써 종양 억제 에도 역할을 하는 것으로 나타났다. ${ }^{29)} \mathrm{miR}-125 \mathrm{~b}$ 는 구강암 세포의 증식을 유의미하게 감소시킨다. ${ }^{30)} \mathrm{miR}-126$ 은 $\mathrm{vascu}^{-}$ lar endothelial growth factor (VEGF)-A의 음성 조절기이 며 구강암 환자에서 림프절 전이를 유도한다. 따라서 $\mathrm{miR}-$ 126 의 하향 조절은 $\mathrm{VEGF}-\mathrm{A}$ 와 basic fibroblast growth factor $(\mathrm{bFGF})$ 를 표적으로 하여 혈관신생 및 림프관신생을 유도 한다. ${ }^{31)} \mathrm{miR}-133 \mathrm{a}$ 는 두경부암에서 종양 억제제로 기능하며 두경부암 조직에서 유의미하게 하향 조절된다. ${ }^{32)}$ 다기능 분자 조절기인 miR-138은 구강암에서 자주 하향 조절되는데, 이는 protooncogene인 GNA12 mRNA를 표적화하여 암세포 증

Table 1. Summary of oncogene miRNAs and the proposed target genes

\begin{tabular}{ll}
\hline Dysregulated miRNA & Proposed target gene \\
\hline miR-10b & Unknown \\
miR-21 & PDCD4 PTEN \\
miR-31 & FIH \\
miR-93 & Unknown \\
miR-134 & WWOX, PDCD7 \\
miR-96-5p & PTEN \\
miR-155-5p & STAT3 ARID2 \\
miR-181b & Unknown \\
miR-205-5p & BRCA1, RAD17 \\
miR-21 1 & TGFßRII \\
miR-223 & Unknown \\
miR-361-3p & OSR2 \\
miR-501-5p & CLCA4 \\
miR-762 & PHLPP2, FOXO4
\end{tabular}

miRNA, microRNA
식 및 침범을 강화한다. ${ }^{33)}$ 또한 $\mathrm{miR}-138$ 은 RhoC와 ROCK2 를 표적으로 하여 두경부암 세포 내 세포 이동 및 침입을 조 절한다. ${ }^{34)} \mathrm{miR}-153$ 은 $\mathrm{EMT}$ 를 억제하고 세포의 중간엽 표현형 을 상피세포로 되돌리며 세포 침습 능력을 감소시킨다. miR153 의 낮은 발현도는 SNAI1과 ZEB2를 타깃으로 한 구강암 전이현상과 관련이 있다. ${ }^{35)} \mathrm{miR}-200$ 군은 ZEB1/ZEB2를 표 적화하여 EMT 및 종양 세포 이동을 억제할 수 있다. ${ }^{36)}$ 두경 부암 환자의 국소 림프절에서 $\mathrm{miR}-200 \mathrm{c}$ 의 발현 수준이 감소 되었으며, 일차 종양에서 BMI1의 발현 증가와 관련이 있다. ${ }^{37)}$ $\mathrm{miR}-200$ 계열은 종양 전이와 혈관 신생과 관련된 단백질의 발현을 조절하며, 암에서 감소되는 miRNA이다. miR-222는 구강암에서 종양 억제제로 작용하며, 표적 SOD2 mRNA를 통해 $\mathrm{MMP} 1$ 발현을 간접적으로 조절함으로써 종양 침범과 전이를 억제한다. ${ }^{38)}$ 두경부암에서 miR-363은 protooncogene인 podoplanin (PDPN)의 하향 조절에 의해 전이를 억 제한다. ${ }^{39)}$ 낮은 miR-375 발현 수준은 두경부암 환자의 예후 불량 및 원격전이와 관련이 있다. ${ }^{40)}$ 또한 암 말기에 miR-375 의 낮은 발현 수준은 구강암 세포의 침습력 및 전이와 상관 관계가 있다. ${ }^{41)}$ 두경부암 억제 miRNA에 대하여 Table 2에 정 리하였다.

\section{두경부암 진단 및 예후 바이오마커로서의 miRNA}

miRNA는 세포에서 분비되어 혈액, 타액 및 소변을 포함 한 다양한 체액에서 발견되며 정량화 할 수 있고 매우 안정적 인 특징이 있다. 이러한 이유로 암을 포함한 모든 질병에 대한 비침습적 바이오마커로서 이상적이며, 특히 타액에서 검출될

Table 2. Summary of Suppressor miRNAs and proposed target genes

\begin{tabular}{ll}
\hline Dysregulated miRNA & Proposed target gene \\
\hline miR-1 & TAGLN2 \\
let-7d & Twist, Snail \\
miR-17 and miR-20a & ITGB8 \\
miR-29 & LAMC2, ITGA6, TGF- $\beta$ \\
miR-34b & Unknown \\
miR-99 & IGFIR, mTOR \\
miR-125b & KLF13, CXCL1 and FOXA1 \\
miR-126 & VEGF-A, bFGF \\
miR-133a & MSN \\
miR-138 & GNA12, RhoC and ROCK2 \\
miR-153 & SNAI1 and ZEB2 \\
miR-200 & ZEB1, ZEB2 \\
miR-222 & MMP-1 \\
miR-363 & Podoplanin (PDPN) \\
miR-375 & KLF5, IGF1R, JAK2 \\
\hline
\end{tabular}

miRNA, microRNA 
수 있기 때문에 두경부암을 검출하고 예후를 판단하는 진단 도구가 될 수 있다. 예를 들어 $\mathrm{miR}-125 \mathrm{a}$ 와 $\mathrm{miR}-200 \mathrm{a}$ 는 건 강한 대조군에 비해 구강암 환자의 침에서 과소 발현된다. ${ }^{42)}$ 또한 miRNA 발현양상이 두경부 각 부위마다 다르고 조직의 발달 기원을 반영하며 양성 종양, 비종양성 병변 및 정상 조 직과 암을 구별할 수 있다. 예를 들어 miR-221과 miR-375의 발현비는 높은 특이성과 민감도를 가지며 정상 조직으로부터 종양을 구별하는 데 사용될 수 있다. ${ }^{43}$ 또한 miRNA는 전이 암의 원발 부위를 예측하는 데에도 도움이 된다. 두경부 부위 에서는 전이 암의 최대 $10 \%$ 에서 원발 부위가 불확실한 경우 가 있으며, 이 경우 원발 부위를 알면 방사선치료 시 범위 감 소와 같은 구체적인 치료요법 적용을 통하여 질병의 합병증 을 최소화할 수 있다. ${ }^{44)}$ miRNA 발현 프로파일은 양성 종양 및 질환으로부터 암을 구별하고 두경부 부위의 알려지지 않 은 원발암의 위치를 예측하는 진단 도구로 사용될 수 있다. ${ }^{44}$ 두경부암에서 miR-205와 let-7d의 발현 수준 감소는 국소 재발 가능성이 더 높고 생존기간이 짧아지는 것과 유의미하 게 관련이 있다. ${ }^{23}$ 높은 수준의 miR-205를 사용하여 두경부 암 림프절 전이를 확인할 수도 있다. ${ }^{45}$ 이전 연구에서는 두경 부암에서 $\mathrm{miR}-451$ 의 낮은 발현 수준을 종양 재발의 강력한 예측 변수로 확인했다. 또한, miRNA는 잔여 암조직 제거를 위한 수술 범위를 결정하는 데에도 영향을 미칠 수 있다. ${ }^{46)}$ 이러한 연구 결과들은 miRNA의 발현 변화가 두경부암의 진단 및 예후에 대한 유망한 지표가 될 수 있음을 보여준다.

\section{두경부암에서 HPV 감염 여부와 miRNA}

인간유두종 바이러스(human papillomavirus, HPV)가 있 는 두경부암은 분자 메커니즘과 임상 예후 모두에서 $\mathrm{HPV}$ 없 는 두경부암과 상당히 구별된다. ${ }^{47)} \mathrm{miRNA}$ 발현 패턴은 두경 부암환자의 HPV 상태와 관련이 있는 것으로 밝혀졌다. HPV miRNA 그룹이 확인되었으며, 그 중 miR-15a/miR-16/ $\mathrm{miR} 195 / \mathrm{miR}-497$ 계열, miR-143/miR-145 및 miR-106-363 클러스터는 $\mathrm{HPV}$ 의 경로 형성에 중요한 역할을 하는 것으로 보인다. ${ }^{48)}$ 두경부암 종양 미세환경이 종양 세포와 종양 미세 환경 사이의 교류를 통해 방사선 치료에 대한 종양 반응을 조절할 수 있으며, 특히 HPV 양성 두경부암 엑소좀에서 풍부 하게 발견된 miR-9는 염증 및 선천 면역에 관여하는 peroxisome proliferator-activated receptor의 하향조절을 통해 M1 대식세포 양극화를 유도하는 대식세포에 들어갈 수 있 으며 높은 miR-9은 HPV 양성 두경부암을 방사선 치료에 더 민감하게 만들었고, 추가 생존 분석에서 miR-9의 증가가 예 후 개선과 긍정적인 상관관계가 있음을 시사했다.99)

\section{두경부암에서 치료제로서 miRNA}

miRNA는 예후 및 진단 바이오마커로 이용될 뿐 아니라 치료제로 이용될 수 있다. ${ }^{48)} \mathrm{miRNA}$ 는 수많은 다른 분자와 상호작용함으로써 많은 생물학적 활성을 조절하기 때문에 효 과적인 치료 표적이 될 수 있다. ${ }^{50}$ 각 miRNA에 맞추어 합성 한 miRNA sponges, ${ }^{51)}$ miR mimics (agomiR), ${ }^{52)}$ miR길항제 $(\text { antagomiR })^{53}$ 및 $\mathrm{miR}$ 억제제 ${ }^{8}$ 의 사용은 종양 유발 및 종양 억제 경로를 조절하여 암의 치료에 이용할 수 있다. miRNA 를 이용한 치료법의 핵심은 하향 조절된 miRNA를 대체하는 물질(miRNA mimic)을 이용하거나, 또는 과발현된 miRNA 에 결합하는 길항제(antagomiR)를 사용하여 변경된 miRNA 농도를 조절하는 것이다. 이러한 치료물질을 사용한 첫 번째 임상 시험은 만성 hepatitis $\mathrm{C}$ virus $(\mathrm{HCV})$ 감염 환자를 대 상으로 시도한 miRNA 타겟 치료제인 Miravirsen으로 임상 2상을 시행하였다. Miravirsen은 miR-122에 결합하고 억제 하는 짧은 oligonucleotide이며 miR-122는 간에서 고도로 발현되며 HCV 전파를 향상시킨다. ${ }^{54)}$ 이 연구는 암에 대한 치료법은 아니었지만, 앞으로 암 치료에 miRNA 이용하는 것 에 대한 많은 희망을 불러일으켰다. 일부 다른 miRNA 치료 법은 전임상 및 임상시험 1 기에 있지만, 몇몇 miRNA는 두경 부암의 치료에 매우 적합할 것으로 기대되고 있다.

\section{종양 억제 miRNA의 보충}

miRNA mimic을 이용하여 종양 억제 기능을 가진 miRNA 보충하기 위한 다양한 전략이 연구되고 있다. 이러한 mimic 은 miRNA 짝의 기능을 모방하는 합성 유도체 올리고뉴클레 오타이드 이중 가닥이다. miRNA mimic의 안정성을 증가시 키고 종양표적화된 전달을 가능하게 하기 위하여 만들어진 치료제를 전신 주입 또는 국소 주입을 통해 전달될 수 있도 록 여러 전달 방법이 연구되었다. 지질 나노 입자에 캡슐화된 miR-34 mimic은 가장 발전된 암의 miRNA 치료제이다. 이는 여러 고형암 및 혈액암을 대상으로 임상 1상(NCT01829971) 을 시험 중이다. miR-34 mimic은 여러 전임상 연구에서 항 암 치료제로서의 가능성을 보여주었다. miR-99a mimics은 구강암세포주에서 세포사멸을 유도함으로써 세포 증식을 감 소시키는 것으로 나타났다. ${ }^{55}$ 또한 miR-100의 복원은 두경부 암세포주의 세포사멸을 증가시킴으로써 세포 이동과 증식을 억제하는 결과를 초래했다. ${ }^{19)}$ 마찬가지로, 암세포들에서 miRle를 transfection 후 뚜렷한 세포 주기 억제와 세포 사망을 보여주었다. ${ }^{20)}$

\section{암 촉진 miRNA (oncomiR)의 억제(antimiRs)}

Antisense oligonucleotides (ASOs), locked 핵산(locked 
nucleic acids) 또는 antagomiRs에 기초한 antimiRs를 사용 하여 oncomiRs의 억제하는 것 또한 항암치료로 이용될 수 있다. AntagomiRs는 숙주 miRNA의 억제를 위해 일반적으 로 사용된다. ${ }^{50)}$ 이러한 AntagomiRs는 두경부암에서 miRNA 의 증가로 인한 효과를 억제시킨다. 즉, antagomir-155는 miRNA-155를 과도하게 발현하는 KB 세포에서 세포 생존 력 감소와 세포 사망을 유발한다. ${ }^{53)}$ AntimiRNAs oligonucleotides (AMOs)로 miRNA-21을 억제했을 때 구강암 세포 주에서 세포사멸 증가, 생존 제한, 증식이 관찰되었다. ${ }^{8}$ 또한 miR-21-AMO의 반복 주입 시 nude mice에서 뚜렷한 세포 자살과 세포증식 감소가 관찰되었으며, 종양을 억제하였다. ${ }^{8)}$ 두경부암에서 miRNA sponge 또는 miRNA mask는 oncomiR를 억제하는 데 사용될 수 있다. miRNA sponge는 표적 miRNA의 전체 계열에 대해 다수의 결합 부위를 갖는 $\mathrm{mRNA}$ 를 표현함으로써 특정 miRNA의 표적 부착을 차단 하여 그 효과를 억제시킨다. 반면, miRNA-masking 기술은 표적 mRNA의 3'UTR에서 miRNA 상호작용 부위에 상보적 인 antisense oligonucleotides로 구성되어 특정 miR-mRNA 쌍 간의 결합을 불안정하게 하여 효과를 나타낸다. ${ }^{50,56)} \mathrm{anti}^{-}$ $\mathrm{miRs}$ 의 치료 가능성에 대한 초기 연구는 유방암 orthotopic 모델을 대상으로 ASOs를 이용하여 miR-10b의 성공적인 억 제를 입증했다. miR-155 유발 림프종의 마우스 모델을 사용 하여 doxycycline 저해로 인해mir-155 발현이 저해됨에 따 라 종양의 크기가 감소되는 것을 확인하였다. 동일 마우스 모 델에서 폴리 나노 입자로 포장된 antimir-155의 전달을 통하 여 종양이 감소되었기에 miR-155의 억제가 치료 가능성을 가질 수 있음을 예상할 수 있다.

\section{결 론}

최근 miRNA에 관한 연구는 꾸준하게 증가되고 있다. 암을 포함한 다양한 질병의 발생에서 수많은 miRNA의 역할이 발견되면서 miRNA를 연구하기 위한 방법론은 더욱 더 발 달하였다. 게놈학과 새로운 시퀀싱 접근법의 출현으로 인해 질병 발현과 관련된 데이터가 증가하며 그 데이터가 공개되고 공유되면서 더욱더 발전된 연구가 가능하게 되었다. The Cancer Genome Atlas (TCGA)와 같은 데이터베이스의 이용 가능성은 전세계 연구자들이 암과 관련된 새로운 miRNA 경 로를 발견하는 데 도움이 되었다. miRNA targetome의 보다 정확한 확인은 miR-cross-linking immunoprecipitation (CLIP) seq와 같은 최근 기술로 가능하다. 최근 연구에 따르 면 miR-CLIP 캡처 기술은 miRNA와 lncRNAs 사이의 새 로운 상호 작용을 식별할 수 있다는 점을 보여주었으며 다른
종류의 비암호화된 RNA가 종종 질병에서 비정상적으로 발 현됨을 밝혔다. 최근 암에서의 lncRNA의 역할에 대한 이해 가 확장되면서 $\operatorname{lncRNA}$ 와 miRNA가 정상 세포의 항상성과 암에서 어떻게 상호 작용하는지에 대한 연구가 활발히 이루 어지고 있다.

암에서 주요 조절 miRNA를 발굴 전략은 miRNA mimics 또는 억제제를 사용하여 게놈 차원의 기능적 스크리닝을 수 행하는 것이다. 본 종설에서 확인한 바에 따르면 두경부암에 서 OncomiR인 miR-21, miR-27a (-3p), miR-31, miR-93, miR-134, miR-146, miR-155, miR-196a, miR-196b, miR211, miR-218, miR-222, miR-372, miR-373은 증가되어 있 었고, 암 억제 miRNA인 let-7a, let-7b, let-7c, let-7d, let7e, let-7f, let-7g, let-7i, miR-26a, miR-99a-5p, miR-137, miR-139-5p, miR-143-3p, miR-184, miR-375는 감소되어 있었다. miRNA 발현은 암의 기원, 병기 및 전이를 반영할 뿐만 아니라 기존 치료법에 대한 민감성/내성을 가진 환자를 구별하기 때문에 앞으로 두경부암의 진단, 예후 및 치료에 대 한 새로운 방향을 제공할 수 있다. miRNA는 조직뿐 아니라 혈액, 소변, 타액 등의 여러 체액에서도 안정적으로 존재하기 때문에 안정적인 분자진단마커가 될 수 있다.

앞으로의 두경부암의 치료에는 oncomiRs의 억제나 anti$\mathrm{miRs}$ 의 공급이 효과적인 전략이 될 수 있다. 아직 miRNA의 효율적인 전신 전달 방법의 개발 및 표적 mRNA에 대한 결 합의 특수성은 중요한 과제로 남아있지만 이 분야의 발전속 도가 빠르기 때문에 근시일 내에 우리는 암 치료의 새로운 패 러다임을 맞이할 수도 있을 것이다.

\section{Acknowledgments}

None

\section{ORCID}

Yeon Soo Kim https://orcid.org/0000-0002-7862-1662

\section{REFERENCES}

1) Liu X, Chen Z, Yu J, Xia J, Zhou X. MicroRNA profiling and head and neck cancer. Comp Funct Genomics 2009;2009:837514.

2) Gomes CC, Gomez RS. MicroRNA and oral cancer: Future perspectives. Oral Oncol 2008;44(10):910-4.

3) Calin GA, Ferracin M, Cimmino A, Di Leva G, Shimizu M, Wojcik SE, et al. A microRNA signature associated with prognosis and progression in chronic lymphocytic leukemia. N Engl J Med 2005;353(17):1793-801.

4) Urbich C, Kuehbacher A, Dimmeler S. Role of microRNAs in vascular diseases, inflammation, and angiogenesis. Cardiovasc Res 2008;79(4):581-8.

5) Severino P, Brüggemann H, Andreghetto FM, Camps C, Klingbeil Mde F, de Pereira WO, et al. MicroRNA expression profile in head and neck cancer: HOX-cluster embedded microRNA-196a and microRNA-10b dysregulation implicated in cell proliferation. BMC 
Cancer 2013;13:533.

6) Lu YC, Chen YJ, Wang HM, Tsai CY, Chen WH, Huang YC, et al. Oncogenic function and early detection potential of miRNA-10b in oral cancer as identified by microRNA profiling. Cancer Prev Res (Phila) 2012;5(4):665-74 .

7) Reis PP, Tomenson M, Cervigne NK, Machado J, Jurisica I, Pintilie $\mathrm{M}$, et al. Programmed cell death 4 loss increases tumor cell invasion and is regulated by miR-21 in oral squamous cell carcinoma. Mol Cancer 2010;9:238

8) Li J, Huang H, Sun L, Yang M, Pan C, Chen W, et al. MiR-21 indicates poor prognosis in tongue squamous cell carcinomas as an apoptosis inhibitor. Clin Cancer Res 2009;15(12):3998-4008.

9) Hedbäck N, Jensen DH, Specht L, Fiehn AM, Therkildsen MH, Friis-Hansen L, et al. MiR-21 expression in the tumor stroma of oral squamous cell carcinoma: An independent biomarker of disease free survival. PLoS One 2014;9(4):e95193.

10) Liu CJ, Tsai MM, Hung PS, Kao SY, Liu TY, Wu KJ, et al. miR-31 ablates expression of the HIF regulatory factor FIH to activate the HIF pathway in head and neck carcinoma. Cancer Res 2010;70(4): 1635-44.

11) Li G, Ren S, Su Z, Liu C, Deng T, Huang D, et al. Increased expression of miR-93 is associated with poor prognosis in head and neck squamous cell carcinoma. Tumour Biol 2015;36(5):3949-56.

12) Fang L, Deng $Z$, Shatseva T, Yang J, Peng C, Du WW, et al. MicroRNA miR-93 promotes tumor growth and angiogenesis by targeting integrin- $\beta 8$. Oncogene 2011;30(7):806-21.

13) Ni YH, Huang XF, Wang ZY, Han W, Deng RZ, Mou YB, et al. Upregulation of a potential prognostic biomarker, miR-155, enhances cell proliferation in patients with oral squamous cell carcinoma. Oral Surg Oral Med Oral Pathol Oral Radiol 2014;117(2):227-33.

14) Baba $\mathrm{O}$, Hasegawa $\mathrm{S}$, Nagai H, Uchida F, Yamatoji M, Kanno NI, et al. MicroRNA-155-5p is associated with oral squamous cell carcinoma metastasis and poor prognosis. J Oral Pathol Med 2016; 45(4):248-55.

15) Lajer CB, Nielsen FC, Friis-Hansen L, Norrild B, Borup R, Garnæs $\mathrm{E}$, et al. Different miRNA signatures of oral and pharyngeal squamous cell carcinomas: A prospective translational study. Br J Cancer 2011;104(5):830-40.

16) Cervigne NK, Reis PP, Machado J, Sadikovic B, Bradley G, Galloni $\mathrm{NN}$, et al. Identification of a microRNA signature associated with progression of leukoplakia to oral carcinoma. Hum Mol Genet 2009;18(24):4818-29.

17) Chu TH, Yang CC, Liu CJ, Lui MT, Lin SC, Chang KW. miR-211 promotes the progression of head and neck carcinomas by targeting TGFßRII. Cancer Lett 2013;337(1):115-24.

18) Chang KW, Liu CJ, Chu TH, Cheng HW, Hung PS, Hu WY, et al. Association between high miR-211 microRNA expression and the poor prognosis of oral carcinoma. J Dent Res 2008;87(11):1063-8.

19) Chen Z, Jin Y, Yu D, Wang A, Mahjabeen I, Wang C, et al. Downregulation of the microRNA-99 family members in head and neck squamous cell carcinoma. Oral Oncol 2012;48(8):686-91.

20) Nohata N, Sone Y, Hanazawa T, Fuse M, Kikkawa N, Yoshino H, et al. miR-1 as a tumor suppressive microRNA targeting TAGLN2 in head and neck squamous cell carcinoma. Oncotarget 2011;2(1-2): $29-42$.

21) Johnson SM, Grosshans H, Shingara J, Byrom M, Jarvis R, Cheng A, et al. RAS is regulated by the let-7 microRNA family. Cell 2005; 120(5):635-47.

22) Chang CJ, Hsu CC, Chang CH, Tsai LL, Chang YC, Lu SW, et al. Let-7d functions as novel regulator of epithelial-mesenchymal transition and chemoresistant property in oral cancer. Oncol Rep 2011;26(4):1003-10.

23) Childs G, Fazzari M, Kung G, Kawachi N, Brandwein-Gensler M, McLemore M, et al. Low-level expression of microRNAs let-7d and
miR-205 are prognostic markers of head and neck squamous cell carcinoma. Am J Pathol 2009;174(3):736-45.

24) Chang CC, Yang YJ, Li YJ, Chen ST, Lin BR, Wu TS, et al. MicroRNA-17/20a functions to inhibit cell migration and can be used a prognostic marker in oral squamous cell carcinoma. Oral Oncol 2013;49(9):923-31.

25) Kinoshita T, Nohata N, Hanazawa T, Kikkawa N, Yamamoto N, Yoshino H, et al. Tumour-suppressive microRNA-29s inhibit cancer cell migration and invasion by targeting laminin-integrin signalling in head and neck squamous cell carcinoma. Br J Cancer 2013;109(10):2636-45.

26) Roderburg C, Urban GW, Bettermann K, Vucur M, Zimmermann $\mathrm{H}$, Schmidt S, et al. Micro-RNA profiling reveals a role for miR-29 in human and murine liver fibrosis. Hepatology 2011;53(1):209-18.

27) Siemens H, Jackstadt R, Hünten S, Kaller M, Menssen A, Götz U, et al. miR-34 and SNAIL form a double-negative feedback loop to regulate epithelial-mesenchymal transitions. Cell Cycle 2011; 10(24):4256-71.

28) Chen D, Cabay RJ, Jin Y, Wang A, Lu Y, Shah-Khan M, et al. MicroRNA deregulations in head and neck squamous cell carcinomas. J Oral Maxillofac Res 2013;4(1):e2.

29) Xu N, Zhang L, Meisgen F, Harada M, Heilborn J, Homey B, et al. MicroRNA-125b down-regulates matrix metallopeptidase 13 and inhibits cutaneous squamous cell carcinoma cell proliferation, migration, and invasion. J Biol Chem 2012;287(35):29899-908.

30) Chen YF, Wei YY, Yang CC, Liu CJ, Yeh LY, Chou CH, et al. miR$125 \mathrm{~b}$ suppresses oral oncogenicity by targeting the anti-oxidative gene PRXL2A. Redox Biol 2019;22:101140.

31) Sasahira T, Kurihara M, Bhawal UK, Ueda N, Shimomoto T, Yamamoto K, et al. Downregulation of miR-126 induces angiogenesis and lymphangiogenesis by activation of VEGF-A in oral cancer. Br $\mathrm{J}$ Cancer 2012;107(4):700-6.

32) Kinoshita T, Nohata N, Fuse M, Hanazawa T, Kikkawa N, Fujimura L, et al. Tumor suppressive microRNA-133a regulates novel targets: Moesin contributes to cancer cell proliferation and invasion in head and neck squamous cell carcinoma. Biochem Biophys Res Commun 2012;418(2):378-83.

33) Jiang L, Dai $Y$, Liu $X$, Wang $C$, Wang $A$, Chen $Z$, et al. Identification and experimental validation of $\mathrm{G}$ protein alpha inhibiting activity polypeptide 2 (GNAI2) as a microRNA-138 target in tongue squamous cell carcinoma. Hum Genet 2011;129(2):189-97.

34) Liu X, Wang C, Chen Z, Jin Y, Wang Y, Kolokythas A, et al. MicroRNA-138 suppresses epithelial-mesenchymal transition in squamous cell carcinoma cell lines. Biochem J 2011;440(1):23-31.

35) Xu Q, Sun Q, Zhang J, Yu J, Chen W, Zhang Z. Downregulation of miR-153 contributes to epithelial-mesenchymal transition and tumor metastasis in human epithelial cancer. Carcinogenesis 2013; 34(3):539-49.

36) Tamagawa S, Beder LB, Hotomi M, Gunduz M, Yata K, Grenman $\mathrm{R}$, et al. Role of miR-200c/miR-141 in the regulation of epithelialmesenchymal transition and migration in head and neck squamous cell carcinoma. Int J Mol Med 2014;33(4):879-86.

37) Lo WL, Yu CC, Chiou GY, Chen YW, Huang PI, Chien CS, et al. MicroRNA-200c attenuates tumour growth and metastasis of presumptive head and neck squamous cell carcinoma stem cells. J Pathol 2011;223(4):482-95.

38) Liu X, Yu J, Jiang L, Wang A, Shi F, Ye H, et al. MicroRNA-222 regulates cell invasion by targeting matrix metalloproteinase 1 (MMP1) and manganese superoxide dismutase 2 (SOD2) in tongue squamous cell carcinoma cell lines. Cancer Genomics Proteomics 2009;6(3):131-9.

39) Sun Q, Zhang J, Cao W, Wang X, Xu Q, Yan M, et al. Dysregulated miR-363 affects head and neck cancer invasion and metastasis by targeting podoplanin. Int J Biochem Cell Biol 2013;45(3):513-20. 
40) Harris T, Jimenez L, Kawachi N, Fan JB, Chen J, Belbin T, et al. Low-level expression of miR-375 correlates with poor outcome and metastasis while altering the invasive properties of head and neck squamous cell carcinomas. Am J Pathol 2012;180(3):917-28.

41) Siow MY, Ng LP, Vincent-Chong VK, Jamaludin M, Abraham MT, Abdul Rahman ZA, et al. Dysregulation of miR-31 and miR-375 expression is associated with clinical outcomes in oral carcinoma. Oral Dis 2014;20(4):345-51.

42) Park NJ, Zhou H, Elashoff D, Henson BS, Kastratovic DA, Abemayor E, et al. Salivary microRNA: Discovery, characterization, and clinical utility for oral cancer detection. Clin Cancer Res 2009; 15(17):5473-7.

43) Avissar M, Christensen BC, Kelsey KT, Marsit CJ. MicroRNA expression ratio is predictive of head and neck squamous cell carcinoma. Clin Cancer Res 2009;15(8):2850-5.

44) Barker EV, Cervigne NK, Reis PP, Goswami RS, Xu W, Weinreb I, et al. microRNA evaluation of unknown primary lesions in the head and neck. Mol Cancer 2009;8:127.

45) Fletcher AM, Heaford AC, Trask DK. Detection of metastatic head and neck squamous cell carcinoma using the relative expression of tissue-specific mir-205. Transl Oncol 2008;1(4):202-8.

46) Santhi WS, Prathibha R, Charles S, Anurup KG, Reshmi G, Ramachandran $\mathrm{S}$, et al. Oncogenic microRNAs as biomarkers of oral tumorigenesis and minimal residual disease. Oral Oncol 2013;49(6):567-75.

47) Luo XJ, Zheng M, Cao MX, Zhang WL, Huang MC, Dai L, et al. Distinguishable prognostic miRNA signatures of head and neck squamous cell cancer with or without HPV infection. Front Oncol 2020;10:614487.

48) Lajer CB, Garnæs E, Friis-Hansen L, Norrild B, Therkildsen MH,
Glud M, et al. The role of miRNAs in human papilloma virus (HPV)-associated cancers: Bridging between HPV-related head and neck cancer and cervical cancer. Br J Cancer 2017;117(5):e2.

49) Tong F, Mao X, Zhang S, Xie H, Yan B, Wang B, et al. HPV + HNSCC-derived exosomal miR-9 induces macrophage M1 polarization and increases tumor radiosensitivity. Cancer Lett 2020;478:34-44.

50) Iorio MV, Croce CM. MicroRNA dysregulation in cancer: Diagnostics, monitoring and therapeutics. A comprehensive review. EMBO Mol Med 2012;4(3):143-59.

51) Ebert MS, Neilson JR, Sharp PA. MicroRNA sponges: Competitive inhibitors of small RNAs in mammalian cells. Nat Methods 2007; 4(9):721-6.

52) Bader AG, Brown D, Winkler M. The promise of microRNA replacement therapy. Cancer Res 2010;70(18):7027-30.

53) Rather MI, Nagashri MN, Swamy SS, Gopinath KS, Kumar A. Oncogenic microRNA-155 down-regulates tumor suppressor CDC73 and promotes oral squamous cell carcinoma cell proliferation: Implications for cancer therapeutics. J Biol Chem 2013;288(1):60818.

54) Janssen HL, Reesink HW, Lawitz EJ, Zeuzem S, Rodriguez-Torres M, Patel K, et al. Treatment of HCV infection by targeting microRNA. N Engl J Med 2013;368(18):1685-94.

55) Yan B, Fu Q, Lai L, Tao X, Fei Y, Shen J, et al. Downregulation of microRNA 99a in oral squamous cell carcinomas contributes to the growth and survival of oral cancer cells. Mol Med Rep 2012;6(3): 675-81.

56) Choi WY, Giraldez AJ, Schier AF. Target protectors reveal dampening and balancing of Nodal agonist and antagonist by miR-430. Science 2007;318(5848):271-4.

\section{정답 및 해설}

(4)

해 설 이 환자와 마찬가지로 비중격이 주된 호발 부위이며, 면역화학염색에서 S-100, HMB-45, melanin A에 양성을 보인다. 점 막 내의 멜라닌세포에서 발생하며, 색소침착 정도에 따라 비강 내에서 흑색의 종물이 관찰되는 경우와 색소침착이 없는 무 색소형으로도 발견된다. 참고 문헌: 대한이비인후과학회. 이비인후과학:비과. 개정2판. 파주: 군자출판사;2018. p.561-3. 